\title{
ПРОМЕНИ ВО СЕМЕЈСТВОТО ВО МАКЕДОНИЈА
}

\section{Кратка содржина}

Предмет на овој текст е анализа на промените во големината, составот и основните белези на семејствата. Важноста на оваа анализа се согледува во фактот дека семејството претставува посебна институција во чии рамки се одвива биолошката и соичиекономската репродукција на населението. Анализата претставена во овој текст е дескриптивна, базирана на податоцци од пописите за населението, домакинствата и становите, спроведени во 1994 и 2002 година, во Македонија како и пописни податоции во другите пописни години и податоич од виталната статиститика.

Клучни зборови: ДОМАК'ИНСТВО, СЕМЕЈСТВО, МАКЕДОНСКИ КОНТЕКСТ, ПОПИС

\section{Вовед}

Во основа, општествените институции, доколку се менуваат тоа го прават многу бавно. Врз основа на постоечките анализи, од ваквиот тренд на бавно менување отстапуваат бракот и семејството. Фактите говорат дека за повеќе од пет децении структурата на споменатите институции бележи брзи промени. Се забележуваат промени во формата на семејството, релациите помеѓу партнерите, како и раѓањето на деца. Причините се бројни, но и последиците од истите се согледуваат на раздични рамништа и имаат одредено одложено делување.

Во европски контекст, периодот од педесеттите и шеесеттите години на XX век е познат како baby boom, период кога се бележат високи стапки на фертилитет. Во тој период, најголем дел од трошоците за образование, здравје и благосостојба на децата биле покриени од страна на државите, а помалку од страна на семејствата. Дополнително, тоа е период по завршувањето на Втората светска војна и е време на екстремно висок економски развој. Месечните приходи и платите биле високи, вработеноста исто така, а трошоците за домаќинствата за домување не претставувале проблем. Главно овој период се одбележува како време кога остварувањето на улогата родител можела да се оствари без посериозни потешкотии 
(Hobcraft, Kierman, 1995, Hobcraft, 1996, Hantrais, et al 2006, Montoro-Gurich et al, 2019).

Меѓутоа, по еден ваков период на благосостојба, бројот на раѓања на деца почнува да се намалува и тој тренд на намалување опстојува до осумдесеттите и деведесеттите години на XX век кога веќе поради намалениот број на раѓања населението се доведува до под нивото на обнова на населението. Генерално, објаснувањата се должат на тоа што и машкото и женското население претендира да се стекне со повисоко образование од основното ниво, а учеството на жената во работната сила се зголемува. Секако дека ваквата констелација доведува до зајакнување на статусот и улогата на жената во општеството. Дополнително, крајот на XX и почетокот на XXI век се карактеризира како период во кој е потешко да се најде работа, многу е потешко поединците да имаат сопствен дом, а трошоците за домување се во пораст. Несомнено дека еден ваков социјален контекст, кој вклучува и промени на демографското однесување на населението резултира и со промени на моделот на формирање на семејството и раѓањето на деца. Доколку на споменатите фактори се додадат фактите дека модерните средства за контрацепција се лесно достапни, абортусот е сѐ побезбеден и слободен, идните родители имаа простор за индивидуален избор во доменот на сопственото демографско однесување (Caldwell and Schindlmayr 2003, Kalmijn, 2007, Frejka, 2008).

Во еден ваков контекст, опстојувањето на семејството во своите претходни форми и структури е нереално. Современото семејство се усложнува, како од аспект на негово функционирање, така и од аспект на неговата позиција во општеството.

Следејќи ги споменатите временски периоди и со помош на статистички податоци овој труд се фокусира на семејствата во македонски контескт, кој во основа не отстапува од европскиот тренд на демографски развој.

Предмет на овој текст е анализа на промените во големината, составот и основните белези на домаќинствата и семејствата. Важноста на оваа анализа се согледува во фактот дека семејството претставува посебна институција во чии рамки се одвива биолошката и социоекономската репродукција на населението.

Анализата претставена во овој текст е дескриптивна и базирана на податоци од пописите за населението, домаќинствата и становите спроведени во 1994 и 2002 година во тогашна Република Македонија, како и пописни податоци на другите пописни години и податоци од виталната статистика. ${ }^{1}$

\footnotetext{
${ }^{1}$ Пописот за населението, домаќинствата и становите е извор на податоци кој се користи како основа за анализа на домаќинствата и семејствата. Р. Северна Македонија ја нема остварено оваа редовна статистичка активност од 2002 година, со што се нема запазено вообичаениот десетгодишен период за реализација на попис. Овој факт претставува објективно ограничување за испитуваниот предмет на овој труд.
} 


\section{Основни карактеристики на домаќинствата и семејствата}

Домаќинствата се основа за статистичка анализа на семејствата и во таа смисла оваа анализа започнува со основните податоци за нив. Според метододогијата на Државниот завод за статистика (ДЗС), домаќинство претставува „семејство или друга заедница на дица кои изјавиле декаа живеат заедно и заеднички да го трошат буџетот за остварување на своите потреби во домаќинството, храна и други потреби, без оглед дали сите чиенови постојано се наоѓаат во местото каде што е населено домаќинството или некои од нив престојуваат во друго место во или надвор од државата“ (ДЗС, 2005: 10). Според оваа дефиниција, домаќинството е поширока форма од семејството. Поточно, домаќинството ги опфаќа и заедниците на дицата кои немаат оформено семејство, како што се на пример, дицата кои живеат сами иди дицата кои живеат со повеќе членови и немаат воспоставено семејни односи.

Според метододогијата на ДСЗ, семејството, како основна единица за анализа е заедница на маж и жена во брак или партнери кои живеат заедно со нивните родени иди посвоени деца, но кои не се мажени иди женети (ДЗС, 2005: 10). Во основа, оваа определба е во согласност со дефиницијата на семејство во Закон за семејството содржана во член 2: „Семејството е животна заедница на родитеди и деца и други роднини, ако живеат во заедничко домаќинство. Семејството настанува со раѓањето на деца и со посвојување.“2

Статистичките податоци укажуваат дека во изминатиот век, бројот на домаќинствата во Македонија се зголемува, но се намалува нивната големина, односно се намалува бројот на членовите во домаќинството. Споредено со податоците од последниот Попис на населението, домаќинствата и становите (2002 година), бројот на домаќинства е зголемен за прибдижно три пати во однос на пописните податоци од 1921 година кога имало 146.141 домаќинства. Наспроти ова, просечниот број на членови во домаќинствата се намалил за речиси два члена, односно од 5,53 члена во 1921, на 3,58 члена во 2002 година. Во 2002 година, во Македонија имало 564.237 домаќинства, ${ }^{3}$ што е за 12,4\% повеќе од 1994 година.

Во 2002 година, на ниво на држава, просечниот број членови на домаќинство е намален од 3,9 на 3,6 лица. Она што може да се забележи е тоа дека во државава, семејствата се сѐ уште доминантна заедница во која живее населението. Имено, во 2002 година, учеството на населението кое живее во семејните домаќинства ${ }^{4}$ во вкупното население изнесува 93,5\%.

\footnotetext{
2 Закон за семејство (пречистен текст) Службен весник на РМ, бр. 153 од 20.10.2014 година.

3 ДСЗ, Попис на населението, домаќинствата и становите и земјоделските стопанства во Република Македонија, Книга XIII табела 7, стр. 46.

${ }_{4}^{4}$ Домаќинствата се делат на колективни и индивидуални. Индивидуалните домаќинства се делат на семејни (во кои живеат иица со едно иди повеќе семејства) и
} 
Во категоријата несемејни домаќинства 2,7 \% од вкупното население живее во самечки домаќинства, а 3,8 \% во семејства со повеќе чденови. Споредено со европското искуство овие бројки се пониски.

Податоците покажуваат дека семејните домаќинства преовдадуваат, во однос на несемејните. Поточно, во вкупниот број на индивидуални домаќинства, семејните домаќинства учествуваат со 89,6\% (78,4 со едно семејство и $11,2 \%$ со повеќе семејства), а несемејните со 10,4\% (со еден член 9,5\% и $0,9 \%$ со повеќе членови).

Податоците за структурата на домаќинствата ја поддржуваат истата констатација, но и дополнуваат дека постепено се губи формата на заедничко живеење на повеќе генерации под еден кров иди таканареченото проширено семејство. Во периодот помеѓу двата пописа, учеството на домаќинствата со едно семејство, односно нуклеарните семејства во 2002 година се зголемило за 16,3\%, а на повеќесемејните семејства или проширените семејства се намалило за 17,18\%. Поточно, во 1994 година, од вкупниот број на семејства 70,46\% биле нуклеарни, а 29,54\% проширени семејства. Додека, во 2002 година, учеството на нуклеарни семејства се зголемило на 77,01\%, а на проширените се намалило на 22,99\% (види табела 1 ).

Табела 1 Број и процентуална структура на домаќинствата според бројот на семејства, 1994 и 2002

\begin{tabular}{|c|c|c|c|c|c|}
\hline \multirow{2}{*}{ Година } & \multicolumn{2}{|c|}{ Семејства } & \multicolumn{2}{|c|}{$\begin{array}{c}\text { чество во вкупниот број } \\
\text { на семејства (во \%) }\end{array}$} \\
\cline { 2 - 6 } & Вкупно & $\begin{array}{c}\text { Едно } \\
\text { семејство }\end{array}$ & $\begin{array}{c}\text { Повеќе } \\
\text { семејства }\end{array}$ & $\begin{array}{c}\text { Едно } \\
\text { семејство }\end{array}$ & $\begin{array}{c}\text { Повеќе } \\
\text { семејства }\end{array}$ \\
\hline 1994 & 539.555 & 380.171 & 159.384 & 70,5 & 29,5 \\
\hline 2002 & 574.159 & 442.159 & 13.200 & 77,0 & 22,3 \\
\hline
\end{tabular}

Извор за 1994: Завод за статистика, Попис на населението, домаќинствата и становите и земјоделските стопанства во Република Македонија, Книга VIII, табела 14, стр. 42. За 2002: ДЗС, Попис на населението, домаќинствата и становите и земјоделските стопанства во Република Македонија, 2002, година, Книга II, табела 10, стр. 102 - 103.

Манифестираните промени во бројот на домаќинствата и постојната состојба во однос на нивната големина, е последица на раслојувањето на големите домаќинства во мади семејни домаќинства. Тоа е процес кој се случува под влијание на економскиот развој, на намалувањето на бројот на децата во семејството, односно на промените во репродуктивното однесу-

несемејни (во кое живеат сами дица или дица кои живеат заедно, но не претставуваат семејство). ДСЗ, Попис на населението, домаќинствата и становите и земјоделските стопанства во Република Македонија, Книга XIII, стр.10 - 11. 
вање, но и на интензивниот процес на демографското стареење, промената во брачноста, како и поради порастот на разводите на бракови.

\section{Типови на семејства}

Како следен критериум по кој ќе се определи типот на семејството е формата на заедница помеѓу мажот и жената. Истата може да биде во брак ${ }^{5}$ и вон бракот. ${ }^{6}$

Податоците покажуваат дека заедницата во која партнерите живеат во брак е предоминантната основа по која се оформува семејство.

Табела 2. Семејствата според брачноста и родителството, РМ, 1971, 1981, 1994 и 2002

\begin{tabular}{|c|c|c|c|c|}
\hline \multirow{2}{*}{ Тип на семејство } & \multicolumn{4}{|c|}{ Година } \\
\cline { 2 - 6 } & $\begin{array}{c}\mathbf{1 9 7 1} \\
\text { \% (број) }\end{array}$ & $\begin{array}{c}\mathbf{1 9 8 1} \\
\text { \% (број) }\end{array}$ & $\begin{array}{c}\mathbf{1 9 9 4} \\
\text { \% (број) }\end{array}$ & $\begin{array}{c}\mathbf{2 0 0 2} \\
\text { \% (број) }\end{array}$ \\
\hline Брачен пар без деца & 17,6 & $20,3(100.624)$ & $24,5(132.088)$ & $25,3(145.376)$ \\
\hline Брачен пар со деца & 74,4 & $73,6(365.641)$ & $65,9(355.825)$ & $64,5(370.439)$ \\
\hline Заедница без деца & & & & $0,7(3.966)$ \\
\hline Заедница со деца & & & & $0,8(4.573)$ \\
\hline Мајка со деца & 5,9 & $5,0(24.669)$ & $7,7(41.435)$ & $6,9(39.523)$ \\
\hline Татко со деца & 2,1 & $1,1(5.608)$ & $1,9(10.207)$ & $1,8(10.282)$ \\
\hline
\end{tabular}

Извор за 1981, Породице у СФР Југославији. Савезни завод за статистику; табела 5. за 1994 и 2002 исто како табела 1.

5 „Бракот е со закон уредена заедница на живот на маж и жена во која се остваруваат интересите на брачните другари, семејството и општеството“. Закон за семејство „С Службен весник на РМ, бр. 153 од 20.10.2014 година, член 6. Во истиов член се истакнува дека склучувањето на брак е засновано врз слободна волја, заедничка одлука. Минимум возраста за скдучување брак е 18 години, а дицата кои имаат 16 и 17 години може да склучат брак, но под посебни законски одредби.

6 „Заедница на живот на маж и жена која не е заснована во согласност со одредбите на овој закон (вонбрачна заедница) и која траела најмалку една година, е изедначена со брачната заедница во поглед на правото на меѓусебно издржување и имотот стекнат за време на траењето на таа заедница.“ (Закон за семејство „Службен весник на РМ“, бр. 153 од 20.10.2014 година, чл. 13). 
Учеството на семејствата во кои партнерите живеат заедно, но немаат склучено брак, во вкупниот број на семејства изнесува $1,5 \%$, $(0,7$ \% се без деца, а 0,8 со деца). Споредено со европското искуство, ваквата форма на семејни заедници е пониска, но сепак не треба да се остави по страна можноста дека во иднина деинституционадизирање на однесувањето на партнерите по однос на нивните релации нема да се развива со позасилена динамика. Според податоците од пописните години категоријата на семејства со деца е сѐ помала во вкупниот број на семејства. Ако во 1971 година имало 74,4\% семејства со деца, во 1994 процентот изнесува 65,9\% и нешто пониско (64,5\%) во 2002 година. Меѓутоа, доколку на претходната категорија се додаде и категорија „заедница со деца“ може да се каже дека учеството на семејствата со деца изнесува $65,3 \%$ и да се констатира дека нема промена помеѓ 1994 и 2002 година. Наспроти ваквата тенденција семејствата без деца покажуваат зголемување и тоа од 17,6\% во 1971 на 25,3\% во $2002,{ }^{7}$ што се должи на намалување на бројот на раѓања (види табела 2).

Семејствата од само еден родител бележат нерамномерна динамика. Вкупно, во 1971 година имало 8,1\%, во 1981 година 6,1\%, во 1994 година 9,6\%, а во 2002 година пад на 8,7\% на семејства во кои живее еден родител со дете или деца (види табела 2). Она што е јасно, е тоа дека, во рамките на сите набљудувани периоди, учеството на татковците во однос на мајките со деца е понизок. Едно од објаснувањата за раздичната динамика, барем помеѓу 1994 и 2002 година, е во тоа што од 2002 година паровите кои живеат во заедница се забележуваат како посебен тип на семејство.

Независно од фактот дека учеството на дицата кои живеат во заедница и семејствата со еден родител не се застапени во голем обем споредено со европското искуство, сепак треба да се следи динамиката во наредниот период. Потребно е да се истражи нивната диференцираност, мотивите за формирање на ваков вид на заедница и она што е особено значајно е начинот на функционирање и животните стилови.

Генералните согледувања се дека бројот на семејства се зголемува, но големината на семејствата се намалува, а со тоа се менува и составот на семејствата. И, без подлабоки анализи, основната причина за ваквото намалување на бројот на семејствата се должи на намалување на бројот на раѓање деца. Со огдед на тоа дека најголемиот број од живородените деца сѐ уште се раѓаат во бракот, намалувањето на бројот на раѓања, а со тоа и на големината на семејството, се должи на одложувањето на раѓањето на деца ${ }^{8}$ и склопувањето на брак. ${ }^{9}$

\footnotetext{
${ }^{7}$ Бројот е добиен со собирање на брачните парови без деца и заедница без деца во табела 2.

8 Во 1994 година просечната возраст на мајката при раѓање на првото дете била 23,5, а во 2008 година 25,6 години, а во 2001 година 26 години. Во однос на вкупниот број на раѓања, просечната врозраст на мајката се зголемува од 26,8 во 1994 на 27,4 во 2008 година, ДСЗ, Статистички годишник стр. 83.
} 


\section{Семејства со деца}

Општата слика за семејствата во однос на бројот на деца покажува дека една третина од вкупниот број на семејства кои имаат деца се со едно дете. Околу една половина се со две деца и другите помалку од две десетини имаат 3, 4 или 5 и повеќе деца. (види табела 3)

Табела 3: Број и процент на семејства според бројот на деца

\begin{tabular}{|c|c|c|c|c|}
\hline \multirow{2}{*}{ Број на деца } & \multicolumn{4}{|c|}{ Година } \\
\cline { 2 - 5 } & \multicolumn{2}{|c|}{1994} & Број & $\%$ \\
\cline { 2 - 5 } & Број & \% & 424.817 & 100,0 \\
\hline Вкупно & 407.467 & 100,0 & 153.054 & 36,0 \\
\hline Едно & 138.059 & 33,9 & 204.459 & 48,1 \\
\hline Две & 196.770 & 48,3 & 47.871 & 11,3 \\
\hline Три & 47.988 & 11,8 & 13.554 & 3,2 \\
\hline Четири & 15.389 & 3,8 & 5.879 & 1,4 \\
\hline Пет+ & 9.261 & 2,3 & & \\
\hline
\end{tabular}

Извор: исто како табела 2

Анализата на промените помеѓу двата пописни периода не покажува големи промени, но се забележува тенденција на намалено учество на секоја категорија поодделно. Од ваквиот тренд категоријата на семејства со едно дете се зголемила за околу четири проценти во 2002 во однос на 1994 година (од 33,9\% се зголемила на 36,0\%). Намалувањето на стапките на раѓања се потврдува и во однос на структурата на семејствата со деца на возраст помала од 15 години. Споредбата на податоците помеѓу двата пописа говори дека бројот на оваа категорија на семејства е намален од 59,3\% во 1994 на 53,8 \% (52,9\% брачни парови со деца и 0,9\% без деца) во 2002 година.

\section{Самечки домаќинства}

Според дефиницијата за семејството, самечките домаќинства не се семејства. Меѓутоа, тренд на зголемување на учеството на овој тип на домаќинства и во контекст на актуелните демографските трендови, во продолжение ќе се задржиме и на оваа форма на организација на животот. Во

\footnotetext{
9 Во текот на набљудуваниот период, во 1994 година биле регистрирани 8,1 брак на 1.000 жители, во 2004 биле регистрирани 6,9 брака на 1.000 жители и овој број расте до 7,6 во 2007, за да повторно покажува тренд на намалени вредности во наредните години за да во 2010 се забележени 6,9, односно 7,2 склучени брака на 1.000 жители.
} 
земјите на благосостојба овој тип на семејства е сѐ повообичаен особено кај младото население. Тоа се должи на релативното изобилство во кое живеат семејствата и кое на младите лица им дозволува право на резиденцијален избор. Какво е македонското искуство?

Врз основа на податоците добиени од пописите на населението, домаќинствата и зградите, од 1994 и 2002 година во Македонија, се забележува дека учеството на самечките домаќинства во вкупниот број на домаќинства покажува благо зголемување и тоа од 8,9 во 1994 година на 9,5\% во 2002 година. Од аспект на подот доминантни се жените кои живеат сами и тој сооднос (две третини жени и една третина мажи) речиси не е променет во однос на двата пописни периода. (види табела 4) Според возраста, најчесто група на дица кои живеат сами се старите лица, односно дицата од 65 години и повеќе.

Табела 4. Број и процент на самечките домаќинства, по пол

\begin{tabular}{|c|c|c|c|c|}
\hline \multirow{2}{*}{ Пол } & \multicolumn{4}{|c|}{ Години } \\
\cline { 2 - 5 } & \multicolumn{2}{|c|}{$\mathbf{1 9 9 4}$} & \multicolumn{2}{|c|}{$\mathbf{2 0 0 2}$} \\
\cline { 2 - 5 } & $\%$ & Број & $\%$ & Број \\
\hline Машки & 36,46 & 16.273 & 36,40 & 19.605 \\
\hline Женски & 63,54 & 28.364 & 63,60 & 34.256 \\
\hline Вкупно & 100,00 & 44.637 & 100,00 & 53.861 \\
\hline
\end{tabular}

Извор: исто како табела 3

Ваквата структура на домаќинства говори дека да се живее сам во Македонија не е работа на избор, туку резултат на многу околности: од смртта на партнерот, развод на бракот и неможноста да се најде партнер. Во таа смисла останува прашањето зошто е ниско учеството на младите лица во самечки домаќинства? Дали поради тоа што младите лица го почитуваат традиционалниот стил на живот или причините треба да се бараат во ниската економска моќ на населението за да може да вдијае врз проширување на дијапазонот на резиденцијалниот избор?

\section{Заклучни согледувања}

Претставените податоци укажуваат на приближување на македонскиот кон европскиот контекст, во контекст на бројот и на структурата на семејствата и домаќинствата. Во македонски контекст преовладуваат семејства од нуклеарен тип, а тоа се семејства со брачен пар со деца. Големината на семејствата се намалува, а се намалува и населението кое живее во институција семејство, а се зголемува учеството на лица кои живеат во едночлено домаќинство. Се чини дека формата на потполно семејство е без 
некои поголеми промени. Во форма на еднородителски семејства, бројот на мајки кои живеат со своите деца е поголем, во однос на татковците.

Очекувањата се дека семејството како институција да биде подложна на промени во периодот пред нас. Промените ќе се согледуваат во сѐ поголема индивидуализација на животните стилови. Под услов да се зголемува животниот стандард, можно е да дојде до зголемување на самечките домаќинства и тоа на помладото население. Дополнително, животот во заедница иди кохабитациските заедници можно е да се во пораст, но и присуство на некои други форми на заеднички живот. Поради сѐ поприсутниот феномен на стареење на населението, старечките домаќинства ќе бидат во пораст, а особено во руралните средини. Со оглед на тоа дека стапките на фертилитет не покажуваат нагорна насока, недвосмислено е дека просечната големина и на семејствата и на домаќинствата ќе се намалува. Секако за да се добие потполна демографска слика за семејството потребно е да се разгледа составот на семејствата според другите белези како што се нивото на образование, вид на активност, занимање на мажот и жената, етничката припадност, како и по други селектирани белези.

\section{Дитература:}

CALDWELl, J. C. AND T. SCHINDLMAYR., 2003. "Explanations of the fertility crisis in modern societies: A search for commonalities." Population Studies. 57, p. 241-63.

FREJKA, T., 2008. “Determinants of Family Formation and Childbearing during the Societal Transition in Central and Eastern Europe." Demographic Research. 19, p. 139-170.

HANTRAis, L., PhiliPOV, D. AND Billari, C.F., 2006. Policy implications of changing family formation, Population studies, No. 49, Council of Europe Publishing.

HOBCRAFT, J. AND KIERNAN, K., 199.) "Becoming a parent in Europe". Welfare State Programme Discussion Papers (WSP 116). Centre for Analysis of Social Exclusion, The London School of Economics and Political Science, London, UK

HOBCRAFT, J. 1996. Fertility in England and Wales: A Fifty-Year Perspective, Population Studies 50(3), p. 485-524

Kalmijn, M., 2007. “Explaining Cross-National Differences in Marriage, Cohabitation, and Divorce in Europe, 1990-2000." Population Studies. 61, p 24363.

Montoro-Gurich, C., GARCiA-Vivar, C., 2019. The family in Europe: Structure, intergenerational solidarity, and new challenges to family health. Journal of Family Nursery 2019, 25, 1-20. 